\title{
Speech-Language Evaluation of Closed Head Injured Subjects in South Africa: Cultural Applicability and Ecological Validity of a Test Battery
}

\author{
Nola Watt, Claire Penn and Dilys Jones \\ Department of Speech Pathology and Audiology \\ University of the Witwatersrand \\ Johannesburg
}

\begin{abstract}
This paper addresses the communicative outcome of a group of closed head injured (CHI) subjects in South Africa. Communicative outcome is evaluated on one test battery currently used for medico-legal assessments in South Africa. It was found that a number of the tests were sensitive to breakdown in this sample, but that the demographic factors of first language and pre-injury education significantly affected performance on some tests. Many test performances were significantly related to return to work, thus confirming the importance of communicative skills in the workplace, and the speechlanguage pathologist's role in vocational assessment and rehabilitation.
\end{abstract}

\section{OPSOMMING}

Hierdie verslag spreek die gevolge van geslote hoofbeserings by 'n groep Suid-Afrikaanse proefpersone aan. 'n Spesifieke toetsbattery wat tans in Suid Afrika vir regsmediese evaluasies gebruik word, het gedien as instrument om die proefpersone se kommunikasievermoens te ondersoek. Sommige toetse was sensitief vir kommunikasie uitvalle maar sekere demografiese faktore, b.v. moedertaal en opvoedkundige peil voor die hoofbesering, het die proefpersone se prestasie op sommige toetse beïnloed. Baie van die toetse het 'n duidelike verband getoon met die proefpersone se vermoe om terug te keer werk toe. Die belangrikheid van kommunikasie-vermoëns binne die beroepskonteks en die spraak-taalterapeut se rol in beroepsevaluering in rehabilitasie word dus bevestig.

KEY WORDS: closed head injury; communicative outcome; return to work

\section{INTRODUCTION}

Speech-language pathologists in the medico-legal field are called upon daily to describe and quantify communicative deficits as a result of closed head injury (CHI). These clinicians, however, have little empirical or policyrelated guidance as to which tests are indeed sensitive to breakdown in the South African population, and how performance may be affected by certain demographic and cultural factors, for example, educational level. This is important to know when one considers the vast discrepancies in such socio-economic indicators in South Africa. Further, the medico-legal professional is required to prognosticate, beyond a reasonable doubt, whether or not the patient will be able to return to work. Again, this is currently taking place with little scientific insight regarding which communicative skills are most important in the workplace, and which tests are most useful to measure them.

The above difficulties faced by the South African speechlanguage pathologist are highly significant in the light of the extremely high incidence of CHI in South Africa, cited as 316/100 000 (Nell \& Brown, 1990), approximately 50\% higher than abroad. IN addition, dwindling insurance and third party payouts demand that professionals ensure that they are using culturally appropriate and functionally valid tests in order to ensure the strongest possible case for their clients. This study was hence aimed at determining the sensitivity of a test battery already used by a practice involved in medico-legal assessments in South Africa, the effects on performance of early demographic and injury variables, and which test performances were most closely related to return to work. In order to contextualise the results of this study, previous research documenting communication breakdown following head injury will be discussed, as well as the impact of early variables on test performance and research documenting the relationship between communicative skills and vocational success.

\section{COMMUNICATIVE BREAKDOWN FOLLOWING CLOSED-HEAD INJURY}

There has been much debate in the literature regarding the nature and mechanisms underlying communication breakdown following CHI. Early studies in the 1970's and early 1980's assessed and classified the communicative breakdown using traditional aphasia tests. The inci- 
dence of classical aphasic syndromes found within the CHI population ranges from $2 \%$ (Heilman, Safran \& Geschwind, 1971) to 30\% (Sarno, 1988). Hartley and Levin (1990) point out that the lower incidence of classical aphasias tends to be associated with samples of consecutive cases of head injury, which contain a wide range of severity levels, while higher incidences have been reported in samples of CHI admissions to rehabilitation centres, which are likely to be mainly severe injuries.

A number of specific linguistic deficits have also been found to occur relatively often in the absence of a classical aphasic syndrome, and have been termed "subclinical aphasia" (Sarno, 1988). The most common deficit is anomia, measured usually on a confrontation naming task such as the Boston Naming Test (Heilman, Safran \& Geschwind, 1971; Levin, Grossman \& Kelly, 1976). Verbal fluency tasks have also been found to be sensitive measures of anomia (Walsh, 1991). In addition, impaired auditory comprehension, particularly of complex commands as measured by the Token Test, has been found to occur relatively often (Levin et al., 1976; Sarno, 1988; Kreutzer, Gordon, Rosenthal \& Marwitz, 1993).

More recently, the focus of $\mathrm{CHI}$ assessment has shifted to the investigation of more naturalistic forms of language use, these being discourse and pragmatics. It is not surprising that the use of such different tests has led to the identification of very different types of communication impairment. One of the earliest studies which investigated the discourse of $\mathrm{CHI}$ individuals found it to be characterised by impoverished productivity in terms of the number of words produced, the rate of speech, and the percentage of syllables in mazes (Wyckoff, Jensen \& LaPointe, 1984). The amount of content was also consistently reduced in comparison to controls, and the subjects used fewer cohesive ties per communication unit. The researchers summarise these findings by describing CHI discourse as limited in "quantity, efficiency and connectivity” (Wyckoff, Jensen \& La Pointe, 1984).

Other studies investigating discourse have confirmed deficits in the following areas: discourse cohesion (Mentis \& Prutting, 1987; Liles, Coelho, Duffy \& Zalagens, 1989); discourse superstructure and story grammar elements (Chapman, Culhane, Levin et al., 1992; Liles et al., 1989); coherence (Chapman et al., 1992; Glosser \& Deser, 1990); and productivity (Hartley \& Jensen, 1991; Mentis \& Prutting, 1987; Liles et al., 1989).

Within the realm of pragmatics, deficits have been found to occur in all three of the nonverbal, interactional and propositional aspects of communication (Hartley, 1990). Nonverbal deficits in the paralinguistic features of speech fluency, rate of speech and voice quality (Marsh \& Knight, 1991), fluency (Hartley \& Jensen, 1991) and prosody (Milton, Prutting \& Binder, 1984) have been found. The interactional aspects of communication have also been found to be significantly affected after CHI. In particular, inappropriate turn-taking behaviours have been noted (Milton, Prutting \& Binder, 1984; Coelho, Liles \& Duffy, .1991), as well as deficits in "partner-directed behaviour" (Marsh \& Knight, 1991). McDonald (1993) demonstrated significant difficulties in the CHI individual's ability to meet the informational needs of their listeners. Similarly, Irvine (1984) demonstrated disrupted interpersonal skills on Scale A (response to interlocutor) on Penn's (1985) Profile of Communicative Appropriateness. Finally, researchers have demonstrated difficulties in the propositional aspects of communicative interaction following CHI. These include difficulties in topic selection, maintenance, relevance and quantity of verbal output (Milton et al., 1984; Ehrlich, 1988; Penn \& Cleary, 1988).

At this point, it seems to be important to gather information about how a South African sample of CHI individuals perform on a battery of tests in order to confirm patterns of breakdown, as well as which tests appear to be most sensitive in measuring this breakdown.

\section{IMPACT OF EARLY VARIABLES ON OUTCOME/ TEST PERFORMANCE}

Given the fact that about $88 \%$ of the South African population is not first language English speaking, and that about $25 \%$ are illiterate (Central Statistical Services, 1994), understanding the impact of demographic factors on test performance is of paramount importance in South Africa. In most outcome studies, researchers have attempted to identify factors in the head-injured patient's past and related to the injury itself that can account for the outcomes they describe. Few studies, however, have investigated the impact of these effects on communicative outcome. It is only very recently that a systematic discussion of the possible effects of such factors on test performance has been made and preliminary investigations carried out (Coelho, 1995). The need for this empirical information in South Africa is great, particularly in the light of our multicultural and multilingual society, with such a large disparity in socio-economic status among its inhabitants. It is almost impossible to comment on test performance without it.

\section{IMPACT OF COMMUNICATIVE DEFICITS ON RE- TURN TO WORK (RTW)}

Return to work following head injury abroad, and particularly in South Africa is a major concern as insurance and other resource allocations for $\mathrm{CHI}$ individuals diminish. However, few outcome studies have included the assessment of the impact of communication difficulties on the CHI patient's ability to return to work. In the studies which have assessed this relationship, researchers have used widely differing measures of communicative functioning, from standardised aphasia tests to questionnaire items, thus making comparison and generalisation difficult. Also, researchers have tested their subjects at different times-post=onset. Those testing in the acute stage have measured the prognostic value of early language breakdown on later vocational performance (i.e., communicative functioning as a predictor of future performance), while those who have tested breakdown in the chronic stage measure the relationship between communicative and vocational performance at the same time (i.e., communicative functioning as an indicator of outcome). This is useful in that it allows researchers to make hypotheses as to which deficits are affecting performance at the time of testing.

Testing in the acute stage of recovery, Dresśer, Meirowsky, Weiss et al.(1973) found that the early presence of aphasia was a significant predictor of future unemployment. Similarly, Najenson, Groswasser, Mendelsohn and Hackett (1980) found the early presence of aphasia to have an important influence on rehabilitation outcome, and a significant effect on vocational functioning on follow-up. 
Considering communication breakdown as a late indicator of outcome, Brooks, McKinlay, Symington et al. (1987) found that ratings of communicative impairment by relatives or significant others were significantly related to failure to return to work. Two particular communication deficits, the ability to carry on a conversation and to understand a conversation, were highly significant. In a metaanalysis of the predictors and indicators of work status, Crepeau and Scherzer (1993) were able to compare five studies which investigated the relationship between communicative abilities and return to work, and found their results to be relatively homogeneous with communicative abilities having a moderate correlation with return to work. However, they stress that due to the differing measures used in the various studies, it was difficult to come to a closer understanding of exactly what fosters a strong relationship between communication and return to work.

It appears that no detailed study correlating performance on a battery of communication tests and vocational status has been carried out to date. Also, it is only recently that speech-language pathologists have begun working in close collaboration with the vocational rehabilitation team in attempting to evaluate systematically the communicative requirements of the workplace (Fraser \& Baarslag-Benson, 1994).

The aim of this study, therefore, was to evaluate a particular communication test battery, developed and currently used by a speech therapy practice in South Africa, in terms of the following three aspects:

1. sensitivity to breakdown in the chronic stage of recovery;

2. effects of early demographic and injury variables on test performance; and,

3. the relationship between test performance and occupational status.

\section{METHODOLOGY}

A group of fifty $\mathrm{CHI}$ subjects who had been evaluated for medico-legal purposes, was selected based on the followin'́ criteria:

1. The subjects had to speak English as a first langauge, or at least with enough proficiency not to require an interpreter during testing. This limited the cultural diversity of the sample, but aimed to ensure greater test validity;

2. The subjects had to be of working age at the time of testing;

3. Sufficient information had to be available regarding all the communicative functioning, demographic and injury-related variables, and occupational functions for data analysis.

The medico-legal reports of the subjects who fulfilled these criteria were reviewed in detail, and the relevant data was captured on a data recording form, and transferred into a computerised database devised by the first author (Watt, 1996). The aim of this form was to provide a standard method of analysing the reports and recording the data. It includes 197 variables, including demographic information of age at onset, time since onset, gender, preand postinjury educational levels, pre- and postinjury occupational types and status; injury-related information of severity, cause of injury and surgical procedures; and early postinjury variables, e.g., therapy received. The form was designed to be similar to that designed for the Model Sys- tems Database for Traumatic Brain Injury that has been established in the United States of America (Dahmer, Schilling, Hamilton et al., 1993) in order to make it comparable to international databases and yet feasible in a country with fewer resources for detailed assessment and data gathering. Table 1 summarises the demographic, injury and early post-injury factors investigated in this study.

The communication parameters included on the form are comprehensive in scope and reflect the assessment battery (detailed in table 2) of the speech-language pathologists who conducted the medico-legal assessments. This battery was devised on the basis of substantial experience with a wide range of medico-legal assessments $(>200)$, and taps a range of cognitive and linguistic domains, including hearing, motor speech abilities, receptive language, expressive language, reading, writing, verbal reasoning, and pragmatics. The battery utilises a mix-

TABLE 1: Characteristics of the sample

\begin{tabular}{|c|c|c|}
\hline Characteristic & & $\begin{array}{l}\text { Percen- } \\
\text { tage }\end{array}$ \\
\hline Age at onset & $\begin{array}{l}\text { Mean: } 29 \mathrm{y} 10 \mathrm{mo} \\
\text { Sd: } 12 \mathrm{y} 10 \mathrm{mo}\end{array}$ & \\
\hline Time since onset & $\begin{array}{l}\text { Mean: } 3 y \text { } 5 \mathrm{mo} \\
\text { Sd: } 1 \mathrm{y} 5 \mathrm{mo}\end{array}$ & \\
\hline Gender & $\begin{array}{l}\text { Male } \\
\text { Female }\end{array}$ & $\begin{array}{l}74 \\
26\end{array}$ \\
\hline First language & $\begin{array}{l}\text { English } \\
\text { Afrikaans } \\
\text { Zulu/Xhosa } \\
\text { Sotho } \\
\text { Other European }\end{array}$ & $\begin{array}{l}62 \\
16 \\
8 \\
6 \\
8\end{array}$ \\
\hline $\begin{array}{l}\text { Pre-injury } \\
\text { education }\end{array}$ & $\begin{array}{l}\text { Matriculation } \\
\text { certificate or less } \\
\text { Post secondary } \\
\text { school training or } \\
\text { qualifications }\end{array}$ & $\begin{array}{l}50 \\
50\end{array}$ \\
\hline $\begin{array}{l}\text { Pre-injury } \\
\text { occupational } \\
\text { type }\end{array}$ & $\begin{array}{l}\text { Manual worker } \\
\text { Clerical/technical } \\
\text { Professional/executive } \\
\text { Student }\end{array}$ & $\begin{array}{l}12 \\
22 \\
40 \\
26\end{array}$ \\
\hline $\begin{array}{l}\text { Pre-injury } \\
\text { occupational } \\
\text { status }\end{array}$ & $\begin{array}{l}\text { Competitively employed } \\
\text { full time } \\
\text { Full-time student }\end{array}$ & $\begin{array}{l}74 \\
26\end{array}$ \\
\hline Injury severity & $\begin{array}{l}\text { Mild } \\
\text { Moderate } \\
\text { Severe }\end{array}$ & $\begin{array}{l}18 \\
12 \\
70\end{array}$ \\
\hline $\begin{array}{l}\text { Therapy received } \\
\text { post-injury }\end{array}$ & $\begin{array}{l}\text { Speech-language } \\
\text { Occupational } \\
\text { Physio- } \\
\text { Cognitive } \\
\text { Counselling } \\
\text { Vocational } \\
\text { Social services }\end{array}$ & $\begin{array}{l}24 \\
20 \\
52 \\
6 \\
2 \\
2 \\
2\end{array}$ \\
\hline
\end{tabular}


ture of standardised as well as modified, adapted, and novel or clinician-constructed items that have been developed over time in an attempt to meet the unique needs of the South African head injured population. This appears to have been essential in the face of a shortage of relevant materials, and too great a dependence on inappropriate overseas tools.

The form does not record exact test scores, as these are

TABLE 2: Outcome on the Communicative Test Battery

\begin{tabular}{|c|c|c|c|c|c|c|}
\hline Task & Missing & Adequate & Not adequate & Mild & Moderate & Severe \\
\hline Hearing & - & 39 & 11 & 2 & 3 & 6 \\
\hline $\begin{array}{l}\text { Motor speech } \\
\text { Dysarthria } \\
\text { OPE } \\
\text { Dysphagia } \\
\text { Voice } \\
\text { Fluency }\end{array}$ & $\begin{array}{l}- \\
- \\
- \\
-\end{array}$ & $\begin{array}{l}34 \\
28 \\
40 \\
34 \\
28\end{array}$ & $\begin{array}{l}16 \\
22 \\
10 \\
16 \\
22\end{array}$ & $\begin{array}{c}6 \\
14 \\
5 \\
6 \\
9\end{array}$ & $\begin{array}{c}\cdot \\
4 \\
7 \\
4 \\
6 \\
13\end{array}$ & $\begin{array}{l}6 \\
1 \\
1 \\
4 \\
-\end{array}$ \\
\hline $\begin{array}{l}\text { Reception } \\
\text { Token Test } \\
\text { CELF(ambiguities) } \\
\text { CELF(relationships) } \\
\text { TOLC (ambiguities) } \\
\text { Normal conversation } \\
\text { RHCB (alternate word meaning) } \\
\text { RHCB (verbal humour) }\end{array}$ & $\begin{array}{c}5 \\
9 \\
12 \\
26 \\
2 \\
28 \\
43\end{array}$ & $\begin{array}{l}18 \\
19 \\
15 \\
14 \\
42 \\
12 \\
2\end{array}$ & $\begin{array}{c}27 \\
22 \\
23 \\
10 \\
6 \\
10 \\
5\end{array}$ & $\begin{array}{l}11 \\
12 \\
12 \\
3 \\
6 \\
8 \\
2\end{array}$ & $\begin{array}{l}10 \\
8 \\
7 \\
6 \\
- \\
2 \\
2\end{array}$ & $\begin{array}{l}6 \\
2 \\
4 \\
1 \\
- \\
- \\
1\end{array}$ \\
\hline $\begin{array}{l}\text { Expression } \\
\text { Word-finding }^{1} \\
\text { Verbal fluency } \\
\text { Narrative discourse } \\
\text { Procedural discourse } \\
\text { Syntax }^{1} \\
\text { Paraphasias }^{1} \\
\text { Perseverations }^{1} \\
\text { Serial speech }\end{array}$ & $\begin{array}{l}2 \\
3 \\
3 \\
2 \\
1 \\
1 \\
1 \\
1\end{array}$ & $\begin{array}{l}14 \\
12 \\
25 \\
40 \\
44 \\
42 \\
45 \\
48\end{array}$ & $\begin{array}{c}34 \\
35 \\
22 \\
8 \\
5 \\
7 \\
4 \\
1\end{array}$ & $\begin{array}{c}13 \\
17 \\
9 \\
5 \\
5 \\
5 \\
1 \\
-\end{array}$ & $\begin{array}{l}13 \\
12 \\
10 \\
2 \\
- \\
2 \\
3 \\
-\end{array}$ & $\begin{array}{l}8 \\
6 \\
3 \\
1 \\
- \\
- \\
- \\
1\end{array}$ \\
\hline $\begin{array}{l}\text { Reading }^{2} \\
\text { Comprehension } \\
\text { Drawing inferences } \\
\text { Memory }\end{array}$ & $\begin{array}{c}2 \\
11 \\
16\end{array}$ & $\begin{array}{l}31 \\
12 \\
17\end{array}$ & $\begin{array}{l}17 \\
27 \\
17\end{array}$ & $\begin{array}{c}7 \\
10 \\
7\end{array}$ & $\begin{array}{c}9 \\
13 \\
7\end{array}$ & $\begin{array}{l}1 \\
4 \\
3\end{array}$ \\
\hline $\begin{array}{l}\text { Writing } \\
\text { Letter formation } \\
\text { Spelling }\end{array}$ & $\begin{array}{l}2 \\
4\end{array}$ & $\begin{array}{l}20 \\
28 \\
\end{array}$ & $\begin{array}{l}28 \\
18 \\
\end{array}$ & $\begin{array}{l}26 \\
11\end{array}$ & $\begin{array}{l}1 \\
4\end{array}$ & $\begin{array}{l}i \\
1 i \\
3\end{array}$ \\
\hline $\begin{array}{l}\text { Verbal }{ }^{4} \text { reasoning } \\
\text { Speed } \\
\text { Arithmetic }\end{array}$ & $\begin{array}{l}4 \\
3\end{array}$ & $\begin{array}{l}27 \\
22\end{array}$ & $\begin{array}{l}19 \\
25\end{array}$ & $\begin{array}{l}18 \\
13\end{array}$ & $\begin{array}{c}1 \\
10\end{array}$ & $\begin{array}{l:} \\
\\
-\end{array}$ \\
\hline $\begin{array}{l}\text { Pragmatics } \\
\text { Topic control } \\
\text { Relevance } \\
\text { Turn-taking } \\
\text { Quantity } \\
\text { Eye contact } \\
\text { Gesture } \\
\text { Posture }\end{array}$ & $\begin{array}{l}- \\
1 \\
- \\
2 \\
1 \\
1 \\
1\end{array}$ & $\begin{array}{l}28 \\
31 \\
37 \\
29 \\
38 \\
42 \\
45\end{array}$ & $\begin{array}{c}22 \\
18 \\
13 \\
19 \\
11 \\
7 \\
4\end{array}$ & $\begin{array}{l}6 \\
8 \\
5 \\
5 \\
- \\
3 \\
-\end{array}$ & $\begin{array}{c}12 \\
9 \\
7 \\
13 \\
11 \\
4 \\
4\end{array}$ & $\begin{array}{l}4 \\
1 \\
1 \\
1 \\
- \\
- \\
-\end{array}$ \\
\hline
\end{tabular}

\section{KEY:}

1: assessed in spontaneous speech

2: assessed using the TOLC inferences subtest and/or an informal fable task

3: assessed in spontaneous writing task

4: assessed in clinician-constructed verbal arithmetic task

5: assessed in spontaneous speech 


\section{Cultural Applicability and Ecological Validity of a Test Battery}

often not reported in medico-legal reports, which usually describe the performance qualitatively and interpret the test scores. Hence the researchers classified performance on a five point scale according to whether it was above average (1), average (2), intact but slow or showing mild difficulties (3), moderate difficulties (4), and marked or severe difficulties (5), on the basis of the medico-legal report. This appeared to be the most appropriate way of capturing the data. A measure of inter-rater reliability was calculated to ensure that the data-capturer was able to extract this information reliably. An independent speech pathologist completed the "communication" section of the database form for one fifth of the sample, and inter-rater reliability was calculated using Cohens's kappa, a stringent measure of agreement that corrects for chance agreement (Howell, 1992). The following mean kappa values were obtained:

per subject 0.62 ;

per construct: motor speech 0.86 , receptive language 0.62 , expressive language 0.81 , reading 0.87 , writing

1 , verbal reasoning 0.6 , pragmatics 0.73 .

These values indicate "substantial" to "almost perfect" levels of agreement (Landis \& Koch, 1977) and suggest that the data was recorded sufficiently reliably from the medico-legal reports.

The data was analysed according to the three aims. Frequency counts were used to organise the group data, while relationships between variables were calculated using cross-tabulations and chi squared analysis. When sample sizes were small, Fisher's Exact Probability test was used (Siegel, 1956). The five point rating scale describing communicative performance was collapsed into two categories, namely adequate (ratings of 1 and 2) and inadequate (ratings of 3,4 and 5 ) in order to be compatible with $2 \times 2$ contingency tables. This system is similar to the cut-off systems employed by Kreutzer, Gordon, Rosenthal and Marwitz (1993).

\section{RESULTS AND DISCUSSION}

\section{SENSITIVITY OF THE TEST BATTERY}

Table 2 describes the communicative performance of the subjects on the communication test battery. The column labelled "missing" indicates the number of subjects for whom data on a particular test was missing. This figure reveals how the test batteries used changed according to the needs of the patient.

\section{Hearing}

The occurrence of a hearing loss as a result of the head injury in $22 \%$ of this sample is substantially higher than that reported by Giles and Clark-Wilson (1993) of 6 to $8 \%$ of all hospital trauma admissions. It is significant that despite this high incidence, few, if any, had been referred to an audiologist before the time of the medico-legal assessment, which took place a mean of three years postinjury.

\section{Reception}

It would appear from Table 2 that the receptive battery used is indeed sensitive to breakdown in comprehen- sion in this sample as over half of the subjects manifested difficulties on the Revised Token Test, the subtest used from the Clinical Evaluation of Language Function (CELF)(processing relationships and ambiguities) and the Right Hemisphere Communication Battery (RHCB) verbal humour subtest. Just under half manifested difficulties on the Test of Language Comprehension (TOLC) inferences subtest and the alternate word meanings subtest of the RHCB. The most discriminative test on which the most subjects performed poorly was the Revised Token Test, which is considered to be fairly specific and highly diagnostic of comprehension difficulties (Howieson \& Lezak, 1992). This finding confirms previous reports of the prevalence of a specific linguistic deficit in auditory comprehension in the absence of traditional aphasia following closed head injury.

It is interesting to note that few of the subjects appeared impaired in spontaneous conversation. This illustrates the ease with which comprehension difficulties may be masked in conversational exchanges, very often the only medium on which other professionals base their referral to a speech-language therapist.

\section{Expression}

The profile of communicative performance on the expressive tests clearly indicates which tests are sensitive to breakdown in this South African CHI sample. Nearly $70 \%$ exhibited word finding difficulties in connected speech, which confirms previous repots (Thomsen, 1975; Levin, Grossman \& Kelly, 1976; Sarno, 1984), although these authors relied more on confrontational naming tasks for diagnosis. Poor verbal fluency measures also confirm the previously cited sensitivity of this procedure (Walsh, 1991). The narrative discourse task was the third measure which appeared to be very sensitive to breakdown. Although discourse analysis was not detailed, this finding confirms others' results (Kaplan, 1987; Liles et al., 1989; Hartley \& Jensen, 1991).

\section{Reading}

The assessment of reading appeared to be well justified by the poor performance of the individuals, particularly for deeper level comprehension such as drawing inferences from the text. This is what is referred to as intratextual processing (Ulatowska, Chapman \& Johnson, 1992) such as making inferences on the TOLC or recognising the moral of a fable. As with auditory comprehension, these results highlight the importance of assessing deeper comprehension abilities which would otherwise be missed in basic comprehension tasks.

\section{Verbal reasoning}

Regarding verbal reasoning abilities, the results indicate that tests of arithmetic ability, particularly those which are verbally mediated and require understanding of verbal concepts, are highly sensitive to breakdown following head injury. There was a dissociation between speed of processing and arithmetic ability on these tasks. This was characterised by very quick and impulsive calculations with incorrect answers by some and extremely slow working with ultimately correct answers by others. This has implications both for therapy and for vocational placement. 


\section{Pragmatics}

The pragmatic categories included in the data recording form did not appear to be very sensitive to breakdown in this sample. This may have reflected insufficiently detailed pragmatic analysis. Although there were subjects who manifested difficulties on all of the parameters described, none of these were very great, the most sensitive measure being that of topic control (44\% had difficulties), quantity of verbal output (38\%) and relevance $(36 \%)$. The presence of these difficulties does confirm previous reports of pragmatic breakdown following head injury (Miltori, Prutting \& Binder, 1984; Penn \& Cleary, 1988). Interesting significant relationships between the non-verbal behaviour of eye contact and the pragmatic behaviours of topic control and relevance were found. A possible explanation for this may be that eye contact is essential for gaining important cues from the listener which help to regulate and monitor turns and relevance.

In summary, it appears that the communication test battery used for this sample was sensitive enough to detect breakdown in performance in nearly all communicative spheres. Most of the difficulties experienced by this group confirm previous studies and indicate that such difficulties are persistent, even up to a mean of three years post-injury. These findings have great implications for the role of the speech-language pathologist in the rehabilitation of this clinical population.

\section{EARLY PREDICTORS OF COMMUNICATIVE PERFORMANCE}

The impact of early demographic and injury related variables on communicative test performance was assessed. Table 3 highlights the relationships that were found to be significant at alpha $=0.05$.

The subjects' first language was found to be the most significant factor affecting communicative performance. This indicates that first language European language speakers (i.e., English, Afrikaans and other European languages e.g., German) performed significantly better than subjects whose first langauge was an African language. This does not necessarily mean that these tests have no place in a South African test battery, as a number of these tests were also significantly related to occupational outcome (see below). However, it does mean that therapists must be aware of this factor, as well as which tests are not affected by first language (e.g., pragmatic functioning) and therefore to include these for valid testing.

It is striking how small an impact injury severity had

TABLE 3: Significant predictors of communicative outcome (df=1 except for severity where df=2)

\begin{tabular}{|c|c|c|c|c|}
\hline Test & Gender & $\begin{array}{c}\text { First } \\
\text { language }\end{array}$ & Education & Severity \\
\hline Hearing & - & $\begin{array}{c}0.034 \\
*\end{array}$ & - & - \\
\hline Dysarthria & - & - & - & $\begin{array}{c}4.24 \times 10^{3} \\
* *\end{array}$ \\
\hline OPE problems & - & - & - & $\begin{array}{c}0.016 \\
*\end{array}$ \\
\hline Token test & - & $\begin{array}{c}0.031 \\
*\end{array}$ & - & - \\
\hline Understanding normal conversation & - & $\begin{array}{c}0.033 \\
*\end{array}$ & - & - \\
\hline Narrative discourse & - & 0.040 & - & $-\quad$ \\
\hline Procedural discourse & - & - & $\begin{array}{l}0.050 \\
*\end{array}$ & - \\
\hline Reading: comprehension & ' & $\begin{array}{c}5.47 \times 10^{-3} \\
* *\end{array}$ & $\begin{array}{c}0.015 \\
*\end{array}$ & - \\
\hline Reading: drawing inferences & - & - & $\begin{array}{c}\mathrm{X}^{2}=4.41 \\
*\end{array}$ & - \\
\hline Reading: memory & - & 0.044 & - & - \\
\hline Writing: letter formation & $\mathrm{X}^{2}=4.11$ & - & - & - \\
\hline Verbal reasoning: arithmetic & $\mathrm{X}^{2}=5.09$ & - & - & - \\
\hline
\end{tabular}

* significant at 0.05

** significant at 0.01 
on general communicative functioning in the chronic stage of recovery. Severity of injury was significantly related only to motor speech abilities as manifested in dysarthria and OPE difficulties. It appears that, as far as the speechlanguage pathologist is concerned, injury severity may have less of a role to play, particularly in expressive and receptive language, than other cultural factors such as first language and pre-injury education.

\section{RELATIONSHIP BETWEEN COMMUNICATIVE PERFORMANCE AND RTW.}

Performance on each of the communicative tests was correlated with the occupational status of the subjects, i.e., employed or unemployed. Table 4 highlights the significant relationships found between test performance and return to work.

These results show that adequate performance on at least one test in nearly every communicative domain was significantly related to the ability to return to work. This is encouraging regarding the communicative domains tapped in the assessment as well as the tests used for this purpose. The importance and value of the Revised Token Test appears to be underscored by the very strong relationship between performance on this test and return to work. Since, as mentioned previously, the Token Test has been described as relatively specific to, and therefore strongly diagnostic of langauge comprehension difficulties (Howieson \& Lezak, 1992), this finding can confidently be interpreted as confirming the essential role of high level language comprehension abilities within the functional context of the workplace.

The strong relationship between the reading measures and return to work is possibly related to the nature of the sample, the majority of the subjects having been employed in clerical or professional capacities in which reading is essential. These results reveal the high premium placed on literacy in the vocational context.

Surprisingly, none of the pragmatic parameters were significantly associated with whether or not the subject was able to return to work. This is a counter-intuitive result, as many authors suspect that poor pragmatic skills,

TABLE 4: Communicative tests significantly related to $R T W(d f=1)$

\begin{tabular}{|l|l|l|}
\hline Construct & Test & $\mathrm{X}^{2}$ value \\
\hline Motor speech & OPE & $6.148^{*}$ \\
\hline Reception & Token Test & $13.500^{* * *}$ \\
\hline Expression & Narrative discourse & $4.627^{*}$ \\
\hline Reading & Comprehension & $9.52^{* * *}$ \\
\hline & Inferences & $5.110^{*}$ \\
\hline & Memory & $7.771 * *$ \\
\hline Verbal reasoning & Speed & $5.101^{*}$ \\
\hline
\end{tabular}

* significant at 0.05

** significant at 0.01

*** significant at 0.005 particularly interpersonal aspects of communication, would have severe vocational consequences after head injury (Hartley, 1995; Sarno, 1988). It was, however, found that poor turn-taking abilities and abnormal quantity of verbal output were significantly associated with the downgrading of those who had returned to work ( $\mathrm{X}^{2}$ values of 5.109 and 7.670; alpha=0.05). In other words, a significant number of the working subjects who presented with these symptoms had been downgraded at work, either in terms of the time commitments of the job (e.g., part time v. full-time) or the employment conditions (e.g., competitive v. sympathetic employment).

These findings add more empirical weight to the importance of communicative skills in the workplace, and thus address an important gap in the literature. They also provide convincing support for the functional appropriateness of the tests in this communicative test battery, particularly for the medico-legal assessment, as well as the role of the speech-language pathologist in the vocational rehabilitation team for $\mathrm{CHI}$ individuals.

\section{SUMMARY AND CONCLUSIONS}

These results have important clinical implications for the South African speech pathologist involved in the assessment of CHI individuals. They indicate that communicative breakdown is pervasive and persistent following closed head injury, affecting particularly high level linguistic abilities, and that there are a number of tests available, both standardised and non-standardised, which are sensitive to this breakdown. Clinicians must, however, be aware of how the South African cultural and socio-economic milieu affects performance on some of these tests, and interpret their results accordingly. They should also be sure to include tests in their battery appear to be less affected by such variables (e.g., verbal reasoning tasks and pragmatic skills evaluation). In addition, these results highlight the integral importance of communication skills in the workplace, and how poor performance on a number of tests is significantly related to a failure to return to work.

There is a need for the development of policy guidelines by the profession as a whole to guide the continued development and fine-tuning of a sensitive, valid and reliable test battery for the assessment of communicative breakdown following CHI. It is evident that at the present time South African clinicians are using vastly different assessment tools with little empirical basis for their test selection. Results such as these may have relevance in the setting up of such guidelines. Such a policy may also then have implications for the clinician's dealings with insurance companies, providing therapists with greater empirical and political support for their evaluation procedures, results and prognoses.

A number of implications for future research also emerge from these finding. Firstly, the study should be expanded and replicated with a larger number of subjects, particularly of the smaller groups represented here, such as the first language African language speakers. In doing so, the methodology of this study has implications for the possible compilation of a national database for head injury in South Africa such as that set up abroad (Dahmer et al., 1993). A necessary precursor to such a database would be consensus regarding a common minimal test battery for all participating speech therapists and, again, 
the issue of policy guidelines governing such decisions is applicable here.

The empirical confirmation of the importance of communicative skills in the workplace also has implications for further research. While these results confirm the importance of specific communicative skills, such as comprehension, expression and reading, in successful vocational outcome, further research is necessary to determine whether the pattern of demands differs across different occupations. A tool for measuring the communicative demands of a specific workplace is currently being developed at the University of the Witwatersrand, which will be used by clinicians to conduct on-site job skill assessments.

In conclusion, this study has highlighted the areas of persistent weakness in communicative functioning of a group of CHI subjects in South Africa. Tests sensitive to this breakdown have been identified, as well as which test performances are affected by demographic factors such as pre-injury educational level and first langauge. In addition, test performances most closely related to successful reintegration in the workplace have been identified. These results support the role of the speech-language pathologist in the long-term rehabilitation of CHI individuals particularly in the occupational sphere.

\section{REFERENCES}

Brooks, N., McKinlay, W., Symington, C., Beattie, A. \& Campsie, L. (1987). Return to work within the first seven years of severe head injury. Brain Injury, 1, 5-19.

Central Statistical Services (1994). October Household Survey. Statistical Release. P0317.

Chapman, S.B., Culhane, K.A., Levin, H.S., Harward, H., Mendelsohn, D., Ewing-Cobbs, L., Fletcher, J.M. \& Bruce, D. (1992). Narrative discourse after Closed Head Injury in children and adolescents. Brain and Language, 43, 42-65.

Coelho, C.A. (1995). Discourse production deficits following traumatic brain injury: a critical review of the recent literature. Aphasiology, 5, 409-429.

Coelho, C.A., Liles B.Z. \& Duffy, R.J. (1991). Analysis of conversational discourse in head injured adults. Journal of Head Trauma Rehabilitation, 6, 92-99.

Crepeau, F. \& Scherzer, P. (1993). Predictors and indicators of work status after traumatic brain injury: a meta-analysis. Neuropsychological Rehabilitation, 3, 5-35.

Dahmer, E.R., Schilling, M.A., Hamilton, B.B., Bontke, C.F., Englander, J., Kreutzer, J.S., Ragnarsson, K.T. \& Rosenthal, M. (1993). A model systems database for traumatic brain injury. Journal of Head Trauma Rehabilitation, 8, 12-25.

Dresser, A., Meirowsky, A., Weiss, G., McNeel, M., Simon, G. \& Caveness, W. (1973). Gainful employment following head injury. Archives of Neurology, 29, 111-116.

Ehrlich, J.S. (1988). Selective characteristics of narrative discourse in head-injured and normal adults. Journal of Communication Disorders, 21, 1-9.

Fraser, R.T. \& Baarslag-Benson, R. (1994). Cross-disciplinary collaboration in the removal of work barriers after traumatic brain injury. Topics in Language Disorders, 15, 55-67.

Giles, G.M. \& Clark-Wilson, J. (1993). Brain Injury Rehabilitation. A Neurofunctional Approach. London: Chapman and Hall.

Glosser, G. \& Deser, T. (1990). Patterns of discourse production among neurological patients with fluent language disorders. Brain and Language, 40, 67-88.

Hartley, L. (1995). Cognitive-Communicative Abilities Following Brain Injury. A Functional Approach. California: Singular Publishing Group.

Hartley, L.L. (1990). Assessment of functional communication. In D.E. Tupper and K. D. Cicerone (eds). The Neuropsychology of Everyday Life: Assessment and Basic Competencies. (chap. 6). Boston: Kluwer Academic Publishers.

Hartley, L. \& Jensen, P. (1991). Narrative and procedural discourse after closed head injury. Brain Injury, 5, 267-285.

Hartley, L. \& Levin, H. (1990). Linguistic deficits after closed head injury: a current appraisal. Aphasiology, 4, 353-370.
Heilman, K.M., Safran, A. \& Geschwind, N. (1971). Closed head trauma and aphasia. Journal of Neurology, Neurosurgery and Psychiatry, 34, 265-269.

Howe, J.R. \& Miller, C.A (1975). Midbrain deafness following head injury. Neurology, 91, 50-60.

Howell, D.C. (1992). Statistical Methods for Psychology. Belmont, California: Duxbury Press.

Howieson, D.B. \& Lezak, M.D. (1992). The Neuropsychological Evaluation. In S. C. Yudofsky and R. E. Hales (eds). The American Psychiatric Press Textbook of Neuropsychiatry. (2nd ed.) (chap. 5). Washington: American Psychiatric Press, Inc.

Irvine, L. (1984). The Communicative and Cognitive Deficits Following Closed Head Injury. Unpublished undergraduate research report. University of the Witwatersrand, Johannesburg.

Kaplan, D. (1987). Discourse Production in Closed Head Injury. Unpublished Master's dissertation. University of the Witwatersrand, Johannesburg.

Kreutzer J.S., Gordon, W.A., Rosenthal, M. \& Marwitz, J. (1993). Neuropsychological characteristics of patients with brain injury: preliminary findings from a multicentre investigation. Journal of Head Trauma Rehabilitation, 8, 47-59.

Landis, J.R. \& Koch, G.G. (1977). The measurement of observer agreement for categorical data. Biometrics, 33, 159-174.

Levin, H.S., Grossman, R.G. \& Kelly, P J. (1976). Aphasic disorder in patients with closed head injury. Journal of Neurology, Neurosurgery and Psychiatry, 50, 183-193.

Liles, B., Coelho, C., Duffy, R. \& Zalagens, M. (1989). Effects of elicitation procedures on the narratives of normal and closed head-injured adults. Journal of Speech and Hearing Disorders, 54, 356-366.

Marsh, N.V. \& Knight, R.G. (1991). Behavioral assessment of social competence following severe head injury. Journal of Clinical and Experimental Neuropsychology, 13, 729-740.

McDonald, S. (1993). Pragmatic language skills after closed head injury: ability to meet the informational needs of the listener. Brain and Language, 44, 28-46.

Mentis, M. \& Prutting, C.A. (1987). Cohesion in the discourse of normal and head-injured adults. Journal of Speech and Hearing
Research, 30, 88-98.

Milton, S., Prutting, C. \& Binder, G. (1984). Appraisal of communicative competence in head injured adults. In $\mathrm{R}$. Brookshire (ed.). Clinical Aphasiology Conference Proceedings. (p114-123). Minneapolis: BRK Publishers.

Najenson, T., Groswasser, Z., Mendelsohn, L. \& Hackett, P. (1980). Rehabilitation outcome of brain-damaged patients after severe head injury. International Rehabilitation Medicine, 2, 17-22.

Nell, V. \& Brown, D.S.O. (1990), Epidemiology of Traumatic Brain Injury in Johannesburg: Morbidity, Mortality and Etiology. Health Psychology Unit Technical Report No. 1: UNISA and HSRC.

Penn, C. (1985). The profile of communicative appropriateness: a clinical tool for the assessment of pragmatics. South African Journal of Communication Disorders, 32, 18-32.

Penn, C. \& Cleary, J. (1988). Compensatory strategies in the language of closed head injured patients. Brain Injury, $2,3-17$.

Sarno, M.T. (1984), Verbal impairment after closed head injury. Report of a replication study. The Journal of Nervous and Mental Disease, 172, 475-479.

Sarno, M.T. (1988). Head injury: language and speech deficits. Scandinavian Journal of Rehabilitation Medicine, Suppl. 17 ,
55-64.

Siegel, S. (1956). Nonparametric Statistics for the Behavioral Sciences. New York: McGraw-Hill Book Company, Inc.

Thomsen, I.V. (1975). Evaluation and outcome of aphasia in patients with severe closed head trauma. Journal of Neurology, Neurosurgery and Psychiatry, 38, 237-254.

Ulatowska, H. K., Chapman, S.B. \& Johnson, J. (1992). Depth of Information Processing for Discourse in Aphasic and Elderly Patients. Unpublished research.

Walsh, K.W. (1991). Understanding Brain Damage. A Primer of Neuropsychological Evaluation. (2nd ed.) Melbourrie: Churchill Livingstone.

Watt, N.J. (1996) Predictors and Indicators of Outcome following Closed Head Injury in South Africa. Unpublished Master's dissertation. University of the Witwatersrand, Johannesburg.

Wyckoff, I.H., Jensen, P.J., \& LaPointe, L. (1984). Narrative and Procedural Discourse Following. Closed Head Injury. Technical paper presented at ASHA Convention: San Francisco, California. 


\section{INFORMATION FOR CONTRIBUTORS}

The South African Journal of Communication Disorders publishes reports and papers concerned with research, and critically evaluative theoretical and philosophical conceptual issues dealing with aspects of human communication and its disorders, service provision, training and policy.

The South African Journal of Communication Disorders will not accept material which has been published elsewhere or that is currently under review by other publications

\section{MANUSCRIPT STYLE AND REQUIREMENTS}

Manuscripts should be accompanied by a covering letter providing the author's address and telephone numbers. All contributions are required to follow strictly, the style specified in the $P u b$ lication Manual of the American Psychological Assoc. (3rd ed., 1983) (APA Pub. Man.), with complete internal consistency. Four copies of triple-spaced high quality type-written manuscripts with numbered pages, and wide margins should be submitted. They should be accompanied by ONE identical disc copy of the paper. Filenames should include the first author's initials and a clearly identifiable keyword or abbreviation thereof and should be typewritten on the last line of the last page of the Reference List (for retrieval purposes only).

As a rule, contributions should not exceed much more than 30 pages, although longer papers will be accepted if the additional length is warranted. The first page of TWO copies should contain the title of article, name of author(s), and institutional affiliation (or address). In accordance with the APA Pub. Man. style $(1983$, p.23) authors are NOT required to provide qualifications In the remaining two copies, the first page should contain only the title. The second page of all copies, should contain only an abstract ( 100 words), written in English and Afrikaans. Afrikaans abstracts will be provided for overseas contributors. Major headings where applicable should be in the order of METHOD, RESULTS, DISCUSSION, CONCLUSION, ACKNOWLEDGEMENTS, REFERENCES. All paragraphs should be indented.

TABLES AND FIGURES which should be prepared on separate sheets (one per page), should be copied for review purposes and only the copies sent initially. Figures, graphs, and line drawings that are used for publication, however, must be originals, in black ink on good quality white paper, but these will not be required until after the author has been notified of the acceptance of the article. Lettering appearing on these should be uniform and professionally done, allowing for a $50 \%$ reduction in printing. On no account should lettering be typewritten on the illustration. Any explanation or legend should appéar below it and should not be included in the illustration. The titles of tables, which appear above, the figures, which appear below, should be concise but explanatory. Both should be numbered in Arabic numerals in order of appearance. The number of illustrative materials allowed, will be at the discretion of the Editor (usually about 6 ).

\section{REFERENCES}

References should be cited in the text by surname of the author and the date, e.g., Van Riper (1971). Where there are more than two authors, after the first occurrence, et al. after the first author will suffice, except for six or more when et al. may be used from the start. The names of all authors should appear in the Reference List, which should be listed in strict alphabetical order in triple spacing at the end of the article. All references should be included in the List, including secondary sources, (APA Pub. Man. 1983, p. 13). Only acceptable abbreviations of journals may be used, (see DSH ABSTRACTS, October; or The World List of Scientific Periodicals). The number of references should not exceed much more than 30 , unless specifically warranted.

\section{EXAMPLES}

Locke, J.L. (1983). Clinical Psychology: The explanation and treatment of speech sound disorders. $J$. Speech Hear. Disord., 48 339-341.

Penrod, J.P. (1985). Speech discrimination testing. In J. Katz (Ed.), Handbook of clinical audiology (3rd ed.). Baltimore: Williams \& Wilkins.

Davis, G.A. \& Wilcox, M.J. (1985). Adult aphasia rehabilitation: Applied pragmatics. San Diego, CA: College-Hill.

\section{EDITING}

Acceptable manuscripts may be returned to the author for revision. Additional minor changes may also be made at this stage, but a note on the manuscript acknowledging each alteration made by the author, required. The paper is then returned to the editorial committee for final editing for style, clarity and consistency.

\section{REVIEWING SYSTEM}

The peer review of refereeing system is employed as a method of quality control of this publication. Peer reviewers are selected by the editor based on their expertise in the field and each article is sent to two independent reviewers to assess the quality of the manuscript's scientific and technical content. The blind peer review system is employed during which the name of the author/ authors are not disclosed to the reviewers. The editor retains the final responsibility for decisions regarding revision, acceptance or rejection of the manuscript.

REPRINTS: 10 reprints without covers will be provided free of charge.

DEADLINE FOR CONTRIBUTIONS: the preferred date is the 31 st May each year, but papers will be accepted until 30th June by arrangement.

QUERIES, CORRESPONDENCE \& MANUSCRIPTS: should be addressed to The Editor, South African Journal of Communication Disorders, South African Speech-Language-Hearing Association, P.O. Box 600, Wits, 2050, South Africa. 


\section{INLIGTING VIR BYDRAES}

Die Suid-Afrikaanse Tydskrifi vir Kommunikasieafwykings publiseer verslae en artikels wat gemoeid is met navorsing, of handel oor krities evaluerende, teoretiese en filosofiese konseptuele kwessies wat oor menslike kommunikasie en kommunikasieafwykings, diensverskaffing, opleiding en beleid gaan.

Die Suid-Afrikaanse Tydskrif vir Kommunikasieafwykings sal nie artikels aanvaar wat reeds elders gepubliseer is, of wat tans deur ander publikasies oorweeg word nie.

\section{MANUSKRIP STYL EN VEREISTES:}

Manuskripte behoort deur'n dekkingsbrief vergesel te word wat die skrywer se adres en telefoonnommers bevat. Daar word van alle bydraers verwag om die styl, soos gespesifiseer is in die " $P u b$ lication Manual of the American Psychological Assoc. (3rd ed., 1983) (APA Pub. Man."), nougeset te volg met volledige interne ooreenstemming. Manuskripte moet getik, van hoë gehalte en in drievoud spasiëring met wye kantlyne wees. Vier kopieë van die manuskrip moet verskaf word. EEN hiervan moet 'n identiese skyfkopie van die artikel wees. Lêername behoort die eerste skrywer se voorletters en 'n duidelike identifiseerbare sleutelwoord of afkorting daarvan in te sluit en moet op die laaste lyn van die bladsy van die verwysingslys getik word (slegs vir naslaan doeleindes).

As 'n reël moet bydraes nie 30 bladsye oorskry nie, maar langer artikels sal aanvaar word indien die addisionele lengte dit regverdig. Op die eerste bladsy van TWEE van die afskrifte moet die titel van die artikel, naam van die skrywer(s), en instansie (of adres) verskyn. In ooreenstemming met die "APA Publ. Man." se styl word daar NIE van skrywers verwag om enige kwalifikasies te verskaf nie. Op die eerste bladsy van die twee oorblywende afskrifte moet slegs die titel van die artikel verskaf word. Die tweede bladsy van alle afskrifte moet slegs 'n opsomming ( 100 woorde) in beide Engels en Afrikaans bevat. Afrikaanse opsommings sal vir buitelandse bydraers voorsien word Hoofopskrifte moet, waar van toepassing, in die volgende volgorde verskaf word: METODE, RESULTATE, BESPREKINGS, GEVOLGTREKKINGS, ERKENNINGS en VERWYSINGS. Alle paragrawe moet ingekeep word.

TABELLE EN FIGURE wat op afsonderlike bladsye (een bladsy per tabel/illustrasie) moet verskyn, moet vir referent-doeleindes gekopieer word en slegs die kopieë moet inisieel verskaf word. Figure, grafieke en lyntekeninge wat vir publikasie gebruik word, moet egter oorspronklike weergawes wees en moet in swart ink op wit papier van 'n hoë gehalte wees. Die oorspronklikes sal slegs verlang word nadat die artikel vir publikasies aanvaar is. Letterwerk wat op bogenoemde verskyn, moet eenvormig wees, professioneel gedoen word en daar moet in gedagte gehou word dat dit leesbaar moet wees na 'n 50\% verkleining in drukwerk. Letterwerk by illustrasies moet onder geen omstandighede getik word nie. Verklarings of legendes moet nie in die illustrasie nie, maar daaronder, verskyn. Die opskrifte van tabelle (wat bo-aan verskyn), en die onderskrifte van figure, (wat onderaan verskyn), moet beknop, maar verklarend wees. Numering moet deur middel van Arabiese syfers geskied. Tabelle en figure moet in die volgorde waarin hulle verskyn, genommer word. Die aantal tabelle en illustrasies wat ingesluit word, word deur die Redakteur bepaal (gewoonlik nie meer as 6 nie).

\section{VERWYSINGS}

Verwysings in die teks moet voorsien word van die skrywer se van en die datum, b.v., Van Riper (1971). Wanneer daar egter meer as twee skrywers is moet daar na die eerste verskaffing van al die outeurs, van et al. gebruik gemaak word. In die geval waar daar egter ses of meer outeurs ter sprake is moet $e t$ al. van die begin af gebruik word. Al die name van die skrywers moet in die Verwysingslys verskyn wat aan die einde van die artikel voorkom. Verwysings moet alfabeties in trippel spasiëring gerangskik word. Al die verwysings moet in die Verwysingslys verskyn, insluitende sekondêre bronne, ("APA Pub. Man." 1983, p.13). Slegs aanvaarbare afkortings van tydskrifte se titels mag gebruik word, (sien "DSH ABSTRACTS, October"; of The World List of Scientific Periodicals). Die aantal verwysings moet nie meer as $\mathbf{3 0}$ oorskry nie, tensy dit geregverdig is.

\section{LET OP DIE VOLGENDE VOORBEELDE:}

Locke, J.L. (1983). Clinical psychology: The explanation and treatment of speech sound disorders. J. Speech Hear. Disord., 48, 339-341.

Penrod, J.P. (1985). Speech discrimination testing. In J. Katz (Ed.), Handbook of clinical audiology (3rd ed.). Baltimore: Williams \& Wilkins.

Davis, G.A. \& Wilcox, M.J. (1985). Adult aphasia rehabilitation: Applied pragmatics. San Diego, CA.: CollegeHill.

\section{RESENSERING}

Resensering deur vakkundiges word toegepas as 'n metode van kwaliteitskontrole van hierdie publikasie. Resenseerders word deur die redakteur geselekteer op grond van hulle spesiáliskennis en elke artikel word na twee onafhanklike resenseerders gestuur om die kwaliteit van die manuskrip se wetenskaplike en tegniese inhout te beoordeel. Die naam van die outeur/outeurs word nie aan die resenseerder bekend gemaak nie. Die redakteur behou die verantwoordelikheid vir die finale beslissings aangaande wysigings, aanvaarding of afkeuring van die manuskrip.

\section{REDIGERING}

Manuskripte wat aanvaar is, mag na die skrywer teruggestuur word vir hersiening. Addisionele kleiner veranderinge mag ook op hierdie stadium aangebring word, maar'n nota ter aanduiding. van alle veranderinge wat op die manuskrip voorkom, moet verskaf word. Die artikel word dan aan die redaksionele komitee vir finale redigering van styl, duidelikheid en konsekwentheid teruggestuur.

HERDRUKKE: 10 herdrukke sonder omslae sal gratis aan die outeurs verskaf word.

SLUITINGSDATUMS VIR BYDRAES: Bydraes word verkieslik teen 31 Mei elke jaar verwag, maar artikels sal nog tot 30 Junie vir aanvaarding oorweeg word.

NAVRAE, KORRESPONDENSIE EN MANUSKRIPTÉ: moet geadresseer word aan Die Redakteur, Die Suid-Afrikaanse Tydskrif vir Kommunikasieafwykings, Die Suid-Afrikaanse Spraak-Taal-Gehoor Vereniging, Posbus 600, Witś 2050, SuidAfrika. 
